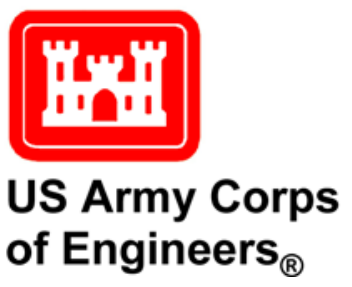

\title{
A Survey of Corrosion and Conditions of Corrosion Protection Systems in Civil Works Structures of the U.S. Army Corps of Engineers
}

by Michael K. Mclnerney, Charles P. Marsh, Vincent F. Hock, and Thomas A. Carlson

PURPOSE: This Coastal and Hydraulics Engineering Technical Note (CHETN) describes the results of a survey conducted among U.S. Army Corps of Engineers (USACE) Districts to document: (a) the presence of corrosion, (b) problems with existing corrosion protection systems, and (c) needs within USACE for additional guidance regarding corrosion and corrosion protection.

BACKGROUND AND OVERVIEW: USACE maintains thousands of hydraulic steel structures (HSS) throughout its 45 districts. Many of these structures suffer from the adverse effects of corrosion. Efforts to minimize the presence of corrosion by using corrosion protection systems have yielded a range of results. Regular inspection, reporting, monitoring, and maintenance are crucial elements of the corrosion protection systems that will allow continued safe use of HSS.

Many of the Corps' HSS are aged beyond their designed lifespan. The replacement cost of these structures is imaginably quite expensive and considering the current fiscal constraints, there is little promise for their replacement in the near future. Compounding the problem is that only the bare minimum expenditure for maintenance of these structures is allotted each year for their continued operation (and sometimes not even that much).

This report provides the findings of a survey undertaken by personnel from the Engineer Research and Development Center-Construction Engineering Research Laboratory (ERDC-CERL) to document the condition of HSS within select Corps districts, their current corrosion protection systems, the degree to which corrosion monitoring and protection is taking place, and other issues pertaining to corrosion detection and prevention. The districts that are represented in this report are those districts who responded to requests for phone conferences to discuss relevant matters. The lack of full participation by all districts makes this report only a small snapshot of all potential problems affecting the Corps' HSS, but the report does offer relevant insight into the items that have been addressed. The cooperation of district personnel who provided their expertise and time is appreciated because their knowledge provided an understanding of the state of corrosion and corrosion protection systems in the Corps's HSS.

MOTIVATION FOR CORROSION PROTECTION MONITORING: The cost of corrosion to the nation exceeded \$1 trillion annually in 2013 (Jackson 2013). A prior study in 2002 reported the nation's annual cost of corrosion was $\$ 276$ billion (Koch et al. 2002). This giant leap in cost within one decade illustrates a tremendous increase in the cost of corrosion to the United States in a relatively short period of time. There is not only the direct monetary cost to be considered, but also a potential indirect cost in lives in the case of future structural failure. These direct and indirect costs have reached all-time highs and are expected to continue climbing even higher according to these reports. 


\section{Report Documentation Page}

Form Approved

OMB No. 0704-0188

Public reporting burden for the collection of information is estimated to average 1 hour per response, including the time for reviewing instructions, searching existing data sources, gathering and maintaining the data needed, and completing and reviewing the collection of information. Send comments regarding this burden estimate or any other aspect of this collection of information,

including suggestions for reducing this burden, to Washington Headquarters Services, Directorate for Information Operations and Reports, 1215 Jefferson Davis Highway, Suite 1204, Arlington

VA 22202-4302. Respondents should be aware that notwithstanding any other provision of law, no person shall be subject to a penalty for failing to comply with a collection of information if it

does not display a currently valid OMB control number.

1. REPORT DATE

SEP 2014

2. REPORT TYPE

3. DATES COVERED

00-00-2014 to 00-00-2014

4. TITLE AND SUBTITLE

A Survey of Corrosion and Conditions of Corrosion Protection Systems

in Civil Works Structures of the U.S. Army Corps of Engineers

6. $\operatorname{AUTHOR}(\mathrm{S})$

5a. CONTRACT NUMBER

5b. GRANT NUMBER

5c. PROGRAM ELEMENT NUMBER

5d. PROJECT NUMBER

5e. TASK NUMBER

5f. WORK UNIT NUMBER

7. PERFORMING ORGANIZATION NAME(S) AND ADDRESS(ES)

8. PERFORMING ORGANIZATION

REPORT NUMBER

U.S. Army Engineer Research and Development

Center,,Vicksburg,,MS,39180

9. SPONSORING/MONITORING AGENCY NAME(S) AND ADDRESS(ES)

10. SPONSOR/MONITOR'S ACRONYM(S)

11. SPONSOR/MONITOR'S REPORT

$\operatorname{NUMBER}(\mathrm{S})$

12. DISTRIBUTION/AVAILABILITY STATEMENT

Approved for public release; distribution unlimited

13. SUPPLEMENTARY NOTES

14. ABSTRACT

15. SUBJECT TERMS

16. SECURITY CLASSIFICATION OF:

a. REPORT

unclassified b. ABSTRACT

unclassified c. THIS PAGE

unclassified
17. LIMITATION OF ABSTRACT

Same as

Report (SAR)
18. NUMBER 19a. NAME OF

OF PAGES RESPONSIBLE PERSON

12 
Regular monitoring can help to identify corrosion and potentially prevent catastrophic failure of key components and structures, but the cost of needed repair or replacement of those components and structures remains present. The presence of a corrosion protection system may or may not be adequate to fully prevent corrosion; however, a properly designed, installed, and maintained corrosion protection system is the only way to actively minimize the costs associated with corrosion.

Early detection and mitigation of corrosion is vital to maintaining critical HSS infrastructure across the Corps, making the Nation's waterways safely navigable for commercial and recreational users. Early detection and repair of corrosion also helps to avoid unnecessary replacement costs for these structures. Regular maintenance is significantly more cost effective than periodic repair or replacement. It is also well documented that the cost of corrosion protection, including initial costs and maintenance costs, is far outweighed by the cost of replacement (Cannon 2013).

This survey work closely supports the statement of work, "Extending the Useful Life of the Nation's Infrastructure" in the ERDC Marketing and Business Development Plan. In particular, our survey identified lock gates and dam gates as critical Corps structures, a finding that makes this work even more closely aligned with the efforts related to the indicated statement of work.

COMMON HSS PROBLEMS: The most common problem identified during the surveys included reduced maintenance of HSS, because longer periods between maintenance result in longer times that a structure is in operation and a related, increased risk that the structure will suffer damage from corrosion. Surface corrosion was reported for many structures as well as loss of section, leading to structural deficiencies.

Corrosion damage takes many forms, and each type of damage is influenced by the conditions to which the structure is subjected. For HSS these conditions include the type of water it is in contact with, the environmental conditions it is exposed to, and the amount and type of use it experiences on a daily or yearly basis.

Specific HSS components that emerged as problematic from the survey include lock miter gates and dam tainter gates. These structures are particularly critical because locks and dams are essential pieces of the Nation's waterways and transportation systems. The economic costs would be significant if one of these structures became inoperable due to the effects of corrosion. These gate structures are large, often weighing thousands of tons, and are very time consuming to repair or replace. A costly and labor-intensive dewatering must precede a gate's repair or replacement, making the dewatering process the major contributing factor to cost of repairs of these gates.

TYPES OF CORROSION PROTECTION SYSTEMS: Two broad categories of protection systems are used to prolong the life of HSS against corrosion: coatings and cathodic protection (CP). Coatings consist of paints, epoxies, enamels, metalizing, and other coatings. CP is a chemical means of polarizing the metal structure so as to reverse the corrosion cell. There are two types of CP systems: sacrificial anode (SA) and impressed current (IC).

An SA system acts much like a dry cell (battery), in that dissimilar metals with different electrical potentials in contact with an electrolyte cause an electrical current through a conducting medium that electrically connects them. One metal becomes the anode, and the other metal becomes the cathode. If chosen properly, the "sacrificial anode" will be more negative, taking the role of the anode, and protecting the structure. The anode is used up in this process and must be replaced 
on a periodic schedule. The maintenance costs are typically low, and the system is fairly reliable. Regular maintenance will ensure the wires are connected at all times.

An IC system is similar, yet instead of relying on natural material potentials to provide a voltage separation, a voltage source acts to drive the current in the opposite direction than would otherwise cause corrosion. This type of system requires constant attention and periodic maintenance; the lack of which can lead to inadequate corrosion protection. These systems are costly, but typically more effective for large structures such as HSS.

CP systems are typically designed according to Engineering Manual (EM) 1110-2-2704, “Cathodic Protection Systems for Civil Works Structures” (Department of Army 2004).

TYPES OF CATHODIC PROTECTION MONITORING SYSTEMS: The use of CP to prevent corrosion of a metal structure is effective only as long as the CP system operates within its intended range. To make sure the system is operating in this range requires periodic monitoring. This can be accomplished with the use of several commercial remote monitoring systems, or time-intensive manual inspection. The remote systems typically rely on telemetry to communicate with the user off-site. Their usefulness far exceeds any system or installation costs as many measurements can be taken (such as off-potential measurements) simultaneously, and remotely, as well as recorded without human interaction. These commercial systems are constantly evolving and adapting to the changing demands of the field. They must be designed specifically to work with the cathodic protection system in question.

Several ERDC-CERL technical reports give details on the selection and robustness of remote CP monitoring systems (VanBlaricum et al. 2001; Stephenson et al. 2007).

TYPES OF CORROSION: The types of corrosion reported in the survey included dissimilar metal corrosion, pitting corrosion, erosion corrosion, and environmentally assisted corrosion. Further reading on the forms of corrosion can be found in Roberge (2008), but the following paragraphs give a brief overview.

Dissimilar metal corrosion (also known as galvanic corrosion) occurs when two different metals are in close contact with one another. Their close proximity allows for electrons to freely pass from one to the other. The electronegativity of each gives rise to the electrical current and the loss of ions on the surface of the component which becomes the anode.

Pitting corrosion occurs on the surface of a single component. Individual grains within the metal become either anodes or cathodes, and adjacent grains become tiny corrosion cells. The cells form small pockets (or pits) in the surface of a metal structure. The pits can eventually pass through the entire section of the component, causing either leaks or loss of strength.

Erosion corrosion occurs when debris, gravel, silt, or other compound acts to wear away at a structure. This wear can first cause any coating to be disturbed, and later will damage the component surface, eventually wearing it down so that the component is no longer capable of supporting its intended design load. Erosion corrosion typically occurs where there is flowing water, which is the medium for transporting the debris.

Environmentally assisted corrosion, as the name suggests, is corrosion that is accelerated by the effects of the environment including temperature, humidity, and stress loading. All these factors were found in the survey results and found to have contributed to corrosion on many HSS. The accelerated corrosion caused by these factors necessitates frequent repair of HSS or mainte- 
nance on a regular schedule. When these schedules are not adhered to, there is the possibility of material failure in a short time.

TYPES OF HSS USED IN THE CORPS: The majority of HSS within the Corps that receive cathodic protection are those within waterways and navigation systems. Lock gates and dam gates are the two largest types. There are more than thousands of separate HSS within the Corps' jurisdiction. The age of these structures range from new to more than $100 \mathrm{yr}$ old. Many are well beyond their designed service life, and their continued use is a testament to their quality construction (phone conversation with Mike Wallace, CP specialist [CESAM-EN-DE], Mobile District).

HSS are typically designed according to EM-1110-2-2105, “Design of Hydraulic Steel Structures" and EM-1110-2-2610, "Mechanical and Electrical Design for Lock and Dam Operating Equipment” (Department of Army 1993, 2013).

Inspection of HSS can occur at any time, but it is typically done when the structure is not submerged under water. This event is called dewatering, and it occurs very infrequently because it requires an extended block of time and incurs significant costs. Inspection of HSS is typically carried out according to EM 1110-2-6054, "Inspection, Evaluation, and Repair of Hydraulic Steel Structures” (Department of Army 2001). Inspections typically look for signs of corrosion as well as structural damage. Alternatively, corrosion potential surveys using a half cell or reference electrode can be carried out when the structure is submerged underwater and while the IC system is instantly turned off. This type of measurement is known as an off-potential measurement. This method is perfected with the use of a current interrupter on the rectifier. Off-potential measurements are more difficult to take for an SA system because a wire must be disconnected.

Traditionally, large structures are protected against corrosion by IC systems, and smaller structures are protected by SA systems. However, depending on the age, location, and other factors, these traditional schemes may not have been employed. Sometimes, the ease of design and installation of SA systems favors their use over IC systems. For other locations, both systems are used to effectively protect a system.

SURVEY DETAILS FROM MOBILE DISTRICT (CESAM): Information obtained in the following section was obtained through phone interviews by the authors on 10 Feb 2014 with structural engineer Allen Davis (CESAM-EN-DA) and on 27 Jan 2014 with Mike Wallace, cathodic protection specialist (CESAM-EN-DE).

The Mobile District is home to the Corrosion Control and Cathodic Protection Systems Technical Center of Expertise (TCX). The district has several waterway systems to oversee, with a wide range of corrosion problems and several CP systems in place. The two major waterways are the Black Warrior River in Alabama and the Tennessee-Tombigbee Waterway in Mississippi. The district has 86 independently operational IC systems. The close interval potential data taken within the last year on 42 of these systems, with very few exceptions (where known repairs or improvements need to be made), are pretty much meeting the NACE SP0169 criteria (NACE 2007) and in accordance with EM 1110-2-2704 guidance (Department of Army 2004).

The district's preference is to install SA CP systems instead of IC CP systems to cathodically protect HSS. However, the selection of SA CP systems over IC systems is not always supported by actual site conditions, design, economic analysis, maintenance records, or actual effectiveness of the installed CP system. Both CP systems are always used in conjunction with protective coat- 
ings. Many of the CP systems within the district have been operating for many years, and some perform better than others due to varying conditions including HSS and CP design by different engineers, age of structure and CP system, repair history (or lack of adequate repairs), operation history, and environmental factors such as water quality and resistivity.

One of the major problems associated with lock gates is structural cracking in the pintle socket area, which may be related at least indirectly (if not directly) to corrosion of the quoin blocks. Various configurations of IC and SA CP systems have been utilized in an attempt to provide more CP current to the quoin and pintle socket areas; however, protective current cannot flow to faces of the wall and gate quoin blocks when they are in contact with each other. Data from potential surveys have indicated that sacrificial rod anodes cannot provide enough driving voltage to supply sufficient protective currents in the quoin areas, particularly in fresh-water environments.

One of the problems described by Mr. Davis is fatigue crack growth resulting from the poor welding usually associated with stress risers and unplanned loading conditions, which ultimately affects the life cycle of the HSS. For example, if the trunnion anchors and gudgeon pins are not properly aligned, this exerts great stress (unplanned loading conditions) on the structure, and crack growth will rapidly increase. Also stress cracks can occur on the HSS as a result of stress risers due to poor welding details and section loss, which can result in crack growth and eventual misalignment of the gate. Corrosion and erosion of the quoin blocks can and often causes considerable damage to the pintle sockets and the entire lower quoin area of the gate, due to loss of bearing on the blocks and formation of alternate load paths. Other locations which are prone to cracking include the diaphragm, fillet welds, and anchor arms.

During dewatering inspections of the HSS, Mr. Davis has often observed excessive corrosion near the bottom of the gate area. This corrosion location can result in many structural stress cracks due to a lack of CP and from metal fatigue. The corrosion rate is unusually high in this area due to debris, the presence of dissimilar metals such as stainless steel used in bolts and sill plates, and the difficulty of providing durable and adequate CP systems in some of these areas.

Additionally, Mr. Davis mentioned that once corrosions starts, it is very difficult to clean and paint these corroded areas. In general, uniform corrosion is rare, but galvanic corrosion between dissimilar metals is common.

Another area of corrosion observed by Mr. Davis is related to the low-carbon stainless steel quoin blocks which are welded to the carbon steel I-beam embedded in the concrete lock wall. This results in severe dissimilar metal and pitting corrosion and stress corrosion cracking in the quoin post area of the gate. Various configurations of IC and SA CP systems have been utilized in an attempt to provide more CP current to the quoin and pintle socket areas; however, protective current cannot flow to faces of the wall and gate quoin blocks when they are in contact with each other (i.e., when gates are mitered).

According to Mr. Davis, the normal time allowed is 30 days to dewater the lock and then clean and repaint the gate structure. This timeframe is generally not long enough to allow the protective coating system to adequately cure. Occasionally, incomplete surface preparation, painting over rust and dirt on the structure, as well as improperly applied paint are found to occur.

A number of structural engineering reports and cathodic protection reports for lock structures were provided by the Mobile District (e.g., USACE CESAM 2011). 
SURVEY DETAILS FROM GALVESTON DISTRICT (CESWG): Information was obtained by the authors through a phone interview on 27 January 2014 with Mike Wallace of the Mobile District.

The problem discussed involves salt-water corrosion of sector gates in Galveston District along the Intracoastal Waterway. The corrosion problems associated with these gates include marine growth, debris impact, and tidal action. For one project, serious challenges were presented to the $\mathrm{CP}$ system and protective coating designer including installation of the CP system under water. Another problem identified is that of floating debris. Floating debris can cause damage to CP systems no matter where they are located, but affects anodes more than any other component.

SURVEY DETAILS FROM NEW ORLEANS DISTRICT (CEMVN): Information was obtained by the authors through phone interviews on 27 January 2014 with Mike Wallace of the Mobile District.

One identified problem was corrosion of $\mathrm{H}$ piles installed in various locations throughout the New Orleans district. H piles are commonly not coated nor protected by CP. The question is what would be the best corrosion prevention and control technologies for $\mathrm{H}$ piles? There have been numerous discussions on using protective coatings only or in combination with $\mathrm{CP}$, or not using any form of corrosion protection and simply increasing the H-pile thickness.

SURVEY DETAILS FROM HUNTINGTON DISTRICT (CELRH): Information was obtained by the authors through phone interviews on 06 March 2014 with John Clarkson, Chief of Structures (CELRH-EC-DS); Douglas Kish, structural engineer; (CELRH-EC-DS); and Brenden McKinley, mechanical engineer, (CELRH-EC-DS). The following paragraphs summarize the types of problems they identified.

The failure of tainter rod anchor rods due to cracking is one of the most prevalent problems within Huntington District. The district cannot monitor the formation of the cracks over time because the rods are dangerous to monitor and the cracks cannot be seen until the rods break. Within the district, the typical tainter gate is $50 \mathrm{yr}$ old, and the only form of corrosion protection when the anchor rod system was installed was a rust inhibitor injected into the annulus between the 1.125in. anchor rod and the 1.250-in. pipe. The typical rod anchor is $60 \mathrm{ft}$ long and anchored to the backing plate with a nut. The rod failure usually occurs near the top of the box.

Another problem for the district is associated with wire rope and their experience with implementing a new plastic-impregnated wire rope product. One of the main problems associated with existing wire rope (that is $60-70 \mathrm{yr}$ old) is the inability to inspect the interior strands of the rope. Thus, when the wire rope is properly lubricated, corrosion is not visible on the exterior strands, but the interior stands can be corroded. One of the problems with the new plastic-impregnated wire rope is the formation of localized corrosion cells and because of the plastic coating, it is harder to inspect.

Also, problems with dissimilar metal corrosion have been observed that are related to contact between the stainless steel wire rope cables and the vinyl-coated metalized surface of the tainter gate. In this situation, the stainless steel wire rope will wear through the metalizing and contact the steel gate surface, causing the dissimilar metal corrosion.

The district is also experiencing corrosion-related problems that are associated with ceramiccoated hydraulic cylinder rods utilized on tainter and miter gates. Corrosion has occurred on the steel rod substrate due to moisture penetrating the ceramic coating. Some of the possible causes 
of the under-film corrosion occurring on the steel substrate are coating porosity and the low cycle rate of the hydraulic cylinder which allows moisture to remain on the ceramic-coated surface for long periods of time without the benefit of the normally protective oil film on the rod's surface which would occur with higher cycling of the cylinder. District personnel did not know they needed to actuate the whole piston each time. The guide spec for this technology did not contain the ceramic-coated option.

The district is moving away from the use of stainless steel miter contact blocks due to dissimilar metal corrosion. Their experience with steel miter contact blocks indicate that a 30-yr life cycle can be achieved by using carbon steel. Other corrosion-related problems discussed include the nickel electroplated components of the top anchorages of miter gates. Premature failure of this nickel coating may be related to the steel surface preparation specifications being utilized before plating. Small pits typically lead to rusting, as there are no good specifications for electroplating.

SURVEY DETAILS FROM ROCK ISLAND DISTRICT (CEMVR): Information was obtained through a phone interview on 7 April 2014 with Frederick Joers in the Engineering and Construction department of the Rock Island District (CEMVR-EC-DS).

The Rock Island District is responsible for the operation and maintenance of 20 lock and dam sites and three reservoirs, most of which date from the 1940s. Typical dam structures include tainter and roller gates. Typical lock structures include sector gates, lift gates, and miter gates. The district performed regularly scheduled repainting up to the 1980s. Due to budget constraints since that time period, repainting has been conducted only during major rehabilitation. This decrease in repainting has led to pitting corrosion on tainter, roller, and miter gate structures. Then, this pitting corrosion is not repaired but is simply recoated. In addition, abrasion has occurred in the valves due to ice flow through the valves. These valves are always submerged and therefore, they are not inspected except during dewatering, during which time they are repaired if needed.

The district generally does not utilize CP except on some floating mooring bitts. CP systems have been installed within Rock Island District with little success, due to their being damaged by ice and debris.

The district's biggest corrosion-related problems occur on tainter (downstream side) and roller gates due to erosion and abrasion of the protective coating systems from debris. The next biggest corrosion-related problems occur to skins plates on roller gates. Other corrosion-related problems include corrosion of the miter gate contact blocks that results in increased loading on the pintle area beyond its original design limit. Also, air chambers on miter gates have exhibited corrosion because it is a moist environment and hard to access when applying adequate coatings).

The district likes the vinyl paint system; however, the problem with it is the length of time between coating applications. There is no set schedule, and the span between coatings can be upwards of $30 \mathrm{yr}$. The coating is not able to sufficiently protect the structure for this time period. Fortunately when coatings are applied, they are applied correctly to USACE guide specifications(USACE 2009) to maximize the potential for adequate protection.

SURVEY DETAILS FROM LOUISVILLE DISTRICT (CELRL): Information was obtained by the authors through a phone interview on 7 April 2014 with Larry Dalton, Chief Navigation Design, Louisville District (CELRL-ED-D-N).

The corrosion-related problems encountered by this district are related to the IC CP systems including generation of hydrogen (exceeding the hydrogen over voltage) at the cathode which 
causes bubbling of the coating, and debris damage to the lead wires and CP anodes. The current policy is to utilize SA CP systems when replacing the CP system on HSS. All new structures (e.g., miter gates, culvert valves) are designed with sacrificial anodes, and the appropriate engineering calculations are performed by a CP expert according to EM 1110-2-2704 guidance (Department of Army 2004). It was noted, however, that the use of SA CP does add considerable weight to the HSS.

Some of the biggest corrosion-related problems encountered by Louisville district are debris damage to the downstream side of the tainter gates (similar to Rock Island district) and erosion corrosion of the skin plate (side arm) which leads to corrosion of the bracing inside of the tainter gate structure.

Problems also exist with dissimilar metal corrosion and debris damage on the miter gates. One of issues with documenting and obtaining funds to repair this type of corrosion-related damage is the difficulty in obtaining funding for dewatering. Louisville District utilizes a 7-yr dewatering maintenance schedule.

The district has experienced some environmentally assisted cracking problems associated with the pintle and quoin block on older miter gates that have had many cycles of operation since the 1960s. Lock and Dam 52/53 were built as temporary HSS many years ago, and thus are well beyond their intended design life.

One last problem identified was the poor design of some HSS, which prevents robust cleaning and recoating of the structure.

SURVEY DETAILS FROM NASHVILLE DISTRICT (CELRN): Information was obtained by the authors through a phone interview on 7 April 2014 with Ronald Carter, a structural engineer and supervisor at the Nashville District (CELRN-EC-CD-CS).

The Nashville District described their corrosion-related problems associated with tainter gates which are primarily utilized for high head flood control. Only one project has water on the downstream side. Most of these structures are more than $70 \mathrm{yr}$ old and were built before current fatigue design requirements. All projects in the district undergo the Corp's Operational Condition Assessment (OCA).

One of the most serious corrosion problems is repainting severely pitted areas of the structure. Some of the pits reach $25 \%-30 \%$ of the wall thickness, resulting in a D rating (using the OCA).

The recoating problems within the district are usually associated with the painting guide specs (Department of Army 1995) and poor painting inspection. In addition, most of the damage to the tainter gates is at the bottom of the gate. It was noted that a badly pitted structure is hard to repaint.

The use of IC CP systems on miter gates within the district has been replaced with SA CP systems due to high maintenance and operational issues associated with the IC CP systems. Sacrificial anodes are replaced as necessary. Inspection is usually done during dewatering events, and there are no corrosion potential surveys taken in the interim. It was noted that the dewatering schedule within Nashville district has increased from a 5-yr cycle to a 7-10-yr cycle, and more breakdown maintenance is being performed due to a lack of maintenance and repair (M\&R) funding. 
In addition, the use of stainless steel around the gate seals is diminishing due to problems with dissimilar corrosion. Galling was specifically noticed for the stainless steel seals.

The problem of alkali silicate reaction (ASR) of concrete at Chickamauga was reported by this district.

SURVEY DETAILS FROM U.S. BUREAU OF RECLAMATION (USBR): The information in the following section was obtained from a visit to ERDC-CERL by Daryl Little and Jessica Torrey on 04 June 2014. They are located in Bureau's office in Denver, CO.

The USBR has under its jurisdiction many of the same HSS types as the Corps of Engineers such as gates, wire rope, and trunnion anchors. In addition, it has many miles of pipeline, power plants and supporting structures, and trash racks. These structures are also prone to corrosion and if not protected, can lead to significant loss or damage to the nation's well being. Pipes are mainly used for water transmission in irrigation. Trash racks are used to keep debris out of pumps and water stations.

Corrosion protection is usually accomplished by coatings or CP. CP systems are designed or approved by the USBR Denver office. When structures are retrofitted for CP, an SA system is usually installed because of the ease of inspection when the structure is out of the water. There is no remote monitoring in use within the USBR.

Common problems associated with corrosion include wire breaks in prestressed concrete cylinder pipe (PCCP), causing severe flooding until the pipe is drained. Aluminum metalizing created problems where the aluminum became the anode. In places where bearings are either underwater or near water, the use of "green" grease led to reduced effectiveness because the grease was water based. In other places, grease was simply missing such as wicket gate bearings. It was agreed that redesigns of structures could lead to easier design of CP systems and application of coatings.

SUMMARY: The above examples demonstrate the trends among the districts in their use of corrosion prevention and control technology. Specific examples include discontinuing the use of IC CP systems in favor of SA CP systems where appropriate due to maintenance and operation problems associated with IC CP systems. In addition, numerous problems with poor-quality coating and painting inspection were documented. The increase in time between dewatering events and periodic inspections has also increased the risk of developing corrosion on HSS. Many of the districts are competing for the necessary funds just to keep their structures operational.

FUTURE WORK: The results of the survey and the information gathered has helped to determine the specific needs of the Corps with regard to corrosion protection and monitoring. ERDCCERL engineers plan to design and build a lab-scale test bed that will verify concurrent computer-based models of CP systems. These models will be capable of determining corrosion potentials on HSS, particularly those with complicated geometry. This capability will help to address the problem of inadequate CP on HSS with complicated geometry which may lack adequate CP coverage on all areas. The laboratory experiment will start by using simple geometry to verify the model and then, progress to more complicated shapes and typical HSS components geometries.

With knowledge gained from the test bed and models, ERDC-CERL engineers plan to conduct a field test and demonstration to determine and validate the effectiveness of our model to design adequate CP and to monitor such CP systems for determining their proper functioning. 
Site visits will be conducted to see firsthand the evidence of corrosion and to experience the corrosion protection systems mentioned in this note. These visits will be coordinated with the appropriate district personnel and coincide with local dewatering schedules.

The full results of this work will culminate in guidance to USACE for CP design and for CP monitoring technologies and implementation strategies. This will necessitate a full technical report, as well as updates to relevant guidance documents such as EMs and guide specifications.

ACKNOWLEDGMENTS AND POINTS OF CONTACT: This CHETN is a product of the Water Resources Infrastructure work package of the Civil Works Business Area being conducted at the U.S. Army Engineer Research and Development Center, Construction Engineering Research Laboratory in Champaign, Illinois.

Questions about this technical note can be addressed to Mr. Michael McInerney (phone: 217373-6759; e-mail: Michael.K.McInerney@usace.army.mil). For information about the Water Resources Infrastructure work package, please contact the program manager, Dr. Jackie Pettway, at 601-634-2288 or Jackie.S.Pettway@usace.army.mil. This technical note should be cited as follows:

McInerney, Michael K., Charles P. Marsh, Vincent F. Hock, and Thomas A. Carlson. 2014. A Survey of Corrosion and Conditions of Corrosion Protection Systems in Civil Works Structures of the U.S. Army Corps of Engineers. ERDC/CHL CHETN-IX-39. Vicksburg, MS: U.S. Army Engineer Research and Development Center.

An electronic copy of this CHETN is available from http://chl.erdc.usace.army.mil/chetn.

\section{REFERENCES}

Cannon, Berry A. 2013. John Hollis Bankhead Lock Miter Gate Cathodic Protection Survey Report, 17--18 July 2013. Mobile, AL: US Army Corps of Engineers, Mobile District.

Department of Army. March 1993. Engineering and Design: Design of Hydraulic Steel Structures. EM-1110-22105. Washington, DC: U.S. Army Corps of Engineers.

April 1995. Engineering and Design: Painting, New Construction and Maintenance. EM 1110-2-3400. Washington, DC: U.S. Army Corps of Engineers.

December 2001. Engineering and Design: Inspection, Evaluation, and Repair of Hydraulic Steel Structures. EM 1110-2-6054. Washington, DC: U.S. Army Corps of Engineers.

. July 2004. Engineering and Design: Cathodic Protection Systems for Civil Works Structures. EM 1110-22704. Washington, DC: U.S. Army Corps of Engineers.

June 2013. Engineering and Design: Mechanical and Electrical Design for Lock and Dam Operating Equipment. EM-1110-2-2610. Washington, DC: U.S. Army Corps of Engineers.

Jackson, Dr. Joshua E. 2013. “Cost of Corrosion Annually in the US over \$1 Trillion.” Houston, TX: G2MT Labs, LLC. Accessed online: http://www.g2mtlabs.com/cost-of-corrosion/.

Koch, Gerhardus H., Michiel P.H. Brongers, Neil G. Thompson, Y. Paul Virmani, and J.H. Payer. 2002. Corrosion Costs and Preventative Strategies in the United States. Publication No. FHWA-RD-01-156. Washington, DC: Federal Highway Administration.

NACE. 2007. SP0169: Standard Practice: Control of External Corrosion on Underground or Submerged Metallic Piping Systems. ISBN 1-57590-035-1. Houston, TX: NACE International

Roberge, Pierre R. 2008. Corrosion Engineering: Principles and Practices. New York: McGraw Hill Professional. 
Stephenson, Larry.D., Ashok Kumar, and J. Bushman. 2007. Remote Monitoring of Cathodic Protection and Cathodic Protection System Upgrades for Tanks and Pipelines at Fort Carson. ERDC/CERL TR-07-25. Champaign, IL: Engineer Research and Development Center.

USACE. 2009. United Facility Guide Specification (UFGS) Division 09 - "Finishes,” Section 0997 02_“Painting: Hydraulic Structures.” UFGS-09 97 02. Available online: https://www.wbdg.org/ccb/DOD/UFGS/UFGS\%2009\%2097\%2002.pdf

USACE CESAM. 2011. "HSS Inspections of Lock Miter Gates during FY 11 Lock De-Waterings Structural: Amory Lock, 14 September 2011.” Mobile, AL: Corps of Engineers, South Atlantic Division Mobile District (CESAM).

VanBlaricum, Vicki L., William R. Norris, James B. Bushman, and Michael J. Szeliga. 2001. Low-Maintenance Remotely Monitored Cathodic Protection Systems. ERDC/CERL TR-01-73. Champaign, IL: Engineer Research and Development Center.

DISCLAIMER: The contents of this technical note are not to be used for advertising, publication, or promotional purposes. Citation of trade names does not constitute an official endorsement or approval of the use of such products. 